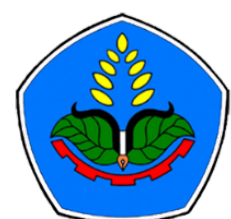

AGROPROSS

National Conference

\title{
Proceedings:
}

Peningkatan Produktivitas Pertanian Era Society 5.0 Pasca Pandemi

Tempat : Politeknik Negeri Jember

Tanggal : 22 Juli 2021

Publisher :

Agropross, National Conference Proceedings of Agriculture

ISBN : 978-623-94036-6-9

DOI : 10.25047 /agropross.2021.217

\section{Efek Ekstrak Basah Daun Plectranthus amboinicus (L.) Terhadap Produksi Susu, Konsumsi Pakan, Pertumbuhan Bobot Badan Tikus dan Anakan}

\author{
Author(s): Kunto Wibisono ${ }^{(1)^{*}}$, Resti Rahma Dianti( ${ }^{(2)}$, Waras Nurcholis ${ }^{(3)}$ \\ (1) Balai Pengkajian Teknologi Pertanian Banten, Kementerian Pertanian \\ (2) Departemen Anatomi Fisiologi Farmakologi, Fakultas Kedokteran Hewan, IPB University \\ (3) Departemen Biokimia, Fakultas Matematika dan Ilmu Pengetahuan Alam, IPB University \\ * Corresponding author: kuntowibisono@pertanian.go.id
}

\begin{abstract}
Lactation insufficiency become a public health problem because it increases the risk of morbidity and mortality for infants. Plectranthus amboinicus (L.) have reported its effect on increasing milk production. In recent years, the wet extraction method using solvent water has not been reported on its effects on milk production. This study aims to 1) obtain the effective dose of wet extract on milk production, feed consumption, the weight growth of rats, and their pups, 2) obtain the optimum time to improve milk production, feed consumption, the weight growth of rats, and their pups, and 3) correlation of milk production, feed consumption, the weight growth of rats and their pups. The study was conducted at Tropical Biopharmaca Research Center, IPB University, from February 2019 to August 2019. Fifteen female rats (Rattus norvegicus) Sprague-Dawley (SD) strain divided into three groups. The first group as a control, the second group was rats gave dose $162 \mathrm{mg} / \mathrm{kgBW}$ (dose 1), and the third group was rats gave dose $324 \mathrm{mg} / \mathrm{kgBW}$ (dose 2). The result of this study showed that dose $324 \mathrm{mg} / \mathrm{kgBW}$ can increased milk production $(2.81 \pm 0.47 \mathrm{~g})$, body weight growth of pups $(18.43 \pm 0.21 \mathrm{~g})$, and feed consumptions of rats $(18.86 \pm 0.18 \mathrm{~g})$ compared to the control $(1.79 \pm 0.89 \mathrm{~g}, 13.39 \pm 0.29 \mathrm{~g}, 13.14 \pm 0.33 \mathrm{~g}$, respectively). Body weight growth of rats on dose 2 decreased $1.79 \pm 0.94 \mathrm{~g}$ compared to control group $0.43 \pm 0.49 \mathrm{~g}$. Optimum time to increased milk production obtained on day 9-16. The improvement of milk production has positive correlation with body weight growth of pups and feed consumptions of rats. On the other side, milk production has negative correlation with body weight growth of rats.
\end{abstract}

\section{Keywords:}

effect;

wet extract;

Plectranthus amboinicus;

milk

production;

rat.

\section{Kata Kunci: ABSTRAK}

efek; Insufisiensi laktasi menjadi masalah kesehatan masyarakat karena meningkatkan risiko kesakitan dan ekstrak basah; kematian bayi. Plectranthus amboinicus (L.) telah dilaporkan efeknya pada peningkatan produksi susu Dalam beberapa tahun terakhir, metode ekstraksi basah menggunakan pelarut air belum dilaporkan pengaruhnya terhadap produksi susu. Penelitian ini bertujuan untuk 1) mendapatkan dosis ekstrak basah

Plectranthus amboinicus; yang efektif terhadap produksi susu, konsumsi pakan, pertumbuhan berat badan tikus dan anakan, 2) memperoleh waktu optimum dalam meningkatkan produksi susu, konsumsi pakan, pertumbuhan berat badan tikus dan anakan, dan 3) mengetahui hubungan produksi susu, konsumsi pakan, pertumbuhan produksi susu; berat badan tikus dan anakan. Penelitian dilakukan di Tropical Biopharmaca Research Center, IPB tikus University, pada Februari 2019 hingga Agustus 2019. Lima belas ekor tikus betina (Rattus norvegicus) galur Sprague-Dawley (SD) dibagi menjadi tiga kelompok. Kelompok pertama sebagai kontrol, kelompok kedua adalah tikus yang diberi dosis $162 \mathrm{mg} / \mathrm{kgBB}$ (dosis 1 ), dan kelompok ketiga adalah tikus yang diberi dosis $324 \mathrm{mg} / \mathrm{kgBB}$ (dosis 2). Hasil penelitian menunjukkan bahwa dosis $324 \mathrm{mg} / \mathrm{kgBB}$ dapat meningkatkan produksi susu tikus $(2,81 \pm 0,47 \mathrm{~g})$, pertumbuhan bobot badan anak tikus $(18,43 \pm$ $0,21 \mathrm{~g})$, dan konsumsi pakan tikus $(18,86 \pm 0,18 \mathrm{~g})$ dibandingkan dengan kontrol (masing-masing 1,79 $\pm 0,89 \mathrm{~g}, 13,39 \pm 0,29 \mathrm{~g}, 13,14 \pm 0,33 \mathrm{~g})$. Pertumbuhan bobot badan tikus pada dosis 2 mengalami penurunan $1,79 \pm 0,94 \mathrm{~g}$ dibandingkan dengan kelompok kontrol $0,43 \pm 0,49 \mathrm{~g}$. Waktu optimal untuk peningkatan produksi susu diperoleh pada hari ke 9-16. Peningkatan produksi susu berkorelasi positif dengan pertumbuhan bobot badan anak tikus dan konsumsi pakan tikus. Di sisi lain, produksi susu berkorelasi negatif dengan pertumbuhan berat badan tikus. 


\section{PENDAHULUAN}

Air susu ibu (ASI) telah diketahui dapat mendukung pertumbuhan dan perkembangan bayi dan balita (Horta et al., 2018), juga memiliki pengaruh positif pada kecerdasan anak (Intelligence Quotient/IQ) (Belfort et al., 2016). ASI sangat direkomendasikan untuk bayi karena nutrisi yang terkandung di dalamnya yang dapat mengoptimalkan pertumbuhan dan perkembangan, dan menyediakan imunitas substansial untuk bayi dari berbagai penyakit. Laktasi juga dapat memberikan interaksi yang intim antara ibu dan anak yang berkaitan dengan pelepasan hormon anti-stres oksitosin (Takahashi, 2021), sehingga bermanfaat bagi kesehatan ibu dan bayi (Belfort et al., 2013). Selain itu, menyusui memberikan nutrisi yang paling tepat dan air yang cukup untuk anak, mengatur kesehatan usus (Akagawa et al., 2019), mencegah infeksi, menurunkan angka kematian neonatal (Silva et al., 2020), mengurangi resiko pendarahan postpartum, menurunkan risiko kanker payudara dan ovarium, mengurangi nyeri postpartum, dan meningkatkan pemulihan postpartum (Desai et al., 2019).

Namun demikian, insufisiensi atau kegagalan laktasi relatif sering terjadi pada wanita, terutama setelah operasi caesar ( $\mathrm{Li}$ et al., 2021). Laporan terbaru menemukan bahwa rasio neutrofil-limfosit dalam darah ibu yang menjalani operasi caesar lebih tinggi daripada persalinan melalui vagina (Kociszewska-Najman et al., 2020), dan sintesis mitokondria adenosin trifosfat menurun, mengakibatkan laktasi tertunda atau insufisiensi laktasi (He \& Xia, 2019). Selain itu, usia, paritas, pendidikan, status sosial ekonomi, agama, struktur keluarga, dan status ibu perkotaan dengan pedesaan juga mempengaruhi terjadinya kegagalan laktasi (Grzeskowiak et al., 2019). Secara global, insufisiensi laktasi merupakan masalah kesehatan masyarakat, karena penggunaan pengganti ASI meningkatkan risiko morbiditas dan mortalitas pada bayi di negara berkembang (Sultana et al., 2013).

Salah satu hal yang dapat dilakukan untuk mengatasi masalah ini adalah menemukan sumber daya alami untuk meningkatkan ASI. Indonesia memiliki banyak potensi bahan alam obat herbal. Salah satu herbal yang sering digunakan ibu setelah melahirkan adalah daun Plectranthus amboinicus (Wibisono et al., 2019). Wanita Batak di Sumatera Utara, biasanya mengkonsumsi tanaman ini segera setelah melahirkan. Mengkonsumsi daun $P$. amboinicus dapat meningkatkan produksi ASI (R. M. Damanik et al., 2017), anti-carcinogenic (Suresh et al., 2020), anti-viral (Bhattacharya et al., 2021), antidiuretic, anti-oxidant (El-hawary et al., 2012), anti-rheumatic (Bhatt et al., 2013), anti-diarrhea (Shubha \& Bhatt, 2015), antibacterial (Aguiar et al., 2015), anti-fungi (Brandao et al., 2013), anti-epileptic (Kumari et al., 2012), anti-streptococcal (Zhang et al., 2017), anti-inflammatory (Chen et al., 2014), anti-dandruff (Selvakumar et al., 2012) and anti-diabetic activities (Govindaraju \& Arulselvi, 2018).

Beberapa penelitian $P$. amboinicus
telah memperlihatkan pengaruhnya terhadap peningkatan produksi susu, berat badan, dan konsumsi pakan. Fraksi etil asetat daun $P$. amboinicus diidentifikasi dapat meningkatkan produksi susu tikus dengan peningkatan ekspresi gen reseptor prolaktin (Iwansyah et al., 2017). Fraksi etil asetat daun $P$. amboinicus dan senyawa bioaktifnya berpotensi sebagai obat untuk merangsang dan meningkatkan produksi ASI (R. M. Damanik et al., 2017). Daun $P$. amboinicus dapat berfungsi sebagai modulator metanogenesis dan biohidrogenasi rumen secara in vitro (Yanza et al., 2018). P. amboinicus pada blok gula merah dapat meningkatkan produksi susu sapi Friesian Holstein (Fati et al., 2014). Suplementasi daun $P$. amboinicus dan Zn-vitamin E dapat 
digunakan untuk meningkatkan metabolisme dan produksi susu, serta kualitas pada kambing etawah (Rumetor, 2008). Ibu menyusui yang mengkonsumsi $P$. amboinicus mengalami peningkatan volume ASI sebesar $65 \%$ selama dua minggu terakhir masa pemberian. Peningkatan ini lebih besar dibandingkan pada ibu menyusui yang mengkonsumsi tablet Molocco+B12 ${ }^{\mathrm{TM}}$ dan Fenugreek (Damanik et al., 2006). Daun $P$. amboinicus terbukti dapat menurunkan tingkat stres ayam pedaging tanpa mengubah profil hematologis dan mengurangi lemak abdomen ayam pedaging (Nengsih, 2020).

Namun, dalam beberapa tahun terakhir, metode ekstraksi basah menggunakan pelarut air belum dilaporkan pengaruhnya terhadap produksi susu, pertumbuhan bobot badan tikus dan anakan, serta konsumsi pakan. Metode ekstraksi basah dengan menggunakan air sebagai pelarut dinilai sangat efisien dalam biaya produksi, selain itu penggunaan air sebagai pelarut dinilai lebih aman untuk dikonsumsi, sehingga diharapkan penggunaan ekstraksi basah daun $P$. amboinicus akan sangat bermanfaat dalam sektor industri. Berdasarkan hal tersebut, penelitian ini bertujuan untuk 1) mendapatkan dosis ekstrak basah yang efektif terhadap produksi susu, konsumsi pakan, dan pertumbuhan bobot badan tikus dan anakan, 2) memperoleh waktu optimum untuk meningkatkan produksi susu, konsumsi pakan, pertumbuhan bobot badan tikus dan anakan, dan 3) mengetahui hubungan produksi susu, konsumsi pakan, pertumbuhan bobot badan tikus dan anakan.

\section{BAHAN DAN METODE Bahan Tanaman}

Daun $P$. amboinicus diambil dari Kebun Walid, Sentul, Bogor, Jawa Barat, Indonesia, ("S -6.56517; "E 106.88836; 336 mdpl), selama bulan September 2018
- Februari 2019. Interval pemotongan daun torbangun adalah 60 hari, dengan jarak antar $25 \mathrm{~cm}$ dari individu yang lain (Purwantari \& Sutedi, 2011). Identifikasi botani dilakukan oleh Dr. J. S Rahajoe, Ahli Botani dari "Herbarium Bogoriense", Pusat Penelitian Biologi, Lembaga Ilmu Pengetahuan Indonesia, dimana spesimen telah disimpan dengan ID

No.145/IPH.1.01/II.8/II 2015.

\section{Ekstrak Basah Daun P. amboinicus}

Penelitian dilakukan di Pusat Penelitian Tropical Biopharmaca, Institut Pertanian Bogor, selama bulan Februari 2019 hingga Agustus 2019. Daun P. amboinicus dibersihkan menggunakan air mengalir kemudian diiris dan diekstraksi dengan air dengan perbandingan 1:3 selama 24 jam. Hasil ekstraksi disaring, kemudian filtratnya diuapkan dengan vacum evaporator pada suhu $50-60^{\circ} \mathrm{C}$ untuk menghasilkan filtrat pekat $4-5 \%$. Untuk menghasilkan serbuk ekstrak daun P. amboinicus, filtrat pekat ditambahkan pati jagung sebanyak 20,45\%, kemudian dicampur merata dan dikeringkan dalam oven pada suhu $50-60^{\circ} \mathrm{C}$. Serbuk ekstrak kering diayak dengan ukuran 100 mesh. Serbuk ekstrak kemudian disterilisasi dengan penyinaran sinar gamma $10 \mathrm{kGy}$ di Badan Tenaga Atom Nasional (BATAN).

\section{Uji Efikasi}

Penelitian ini menggunakan 15 ekor tikus putih (Rattus norvegicus) betina strain Sprague-Dawley (SD) yang terbagi menjadi tiga kelompok (lima ekor tikus untuk setiap kelompok). Kelompok pertama sebagai kelompok kontrol, kelompok kedua adalah tikus yang diberi dosis $162 \mathrm{mg} / \mathrm{kgBB}$ (dosis 1), dan kelompok ketiga adalah tikus yang diberi dosis $324 \mathrm{mg} / \mathrm{kgBB}$ (dosis 2). Semua hewan diaklimatisasi selama seminggu. Tikus diberi pakan dan air minum standar ad libitum. Kondisi penelitian dalam 12 jam terang dan 12 jam gelap. Tikus betina 
dikawinkan dengan tikus jantan dengan perbandingan 2:1. Setelah terjadi kebuntingan pada tikus, masing-masing betina ditempatkan dalam kotak untuk memudahkan pengamatan. Setiap betina hanya dapat menyusui enam ekor anak. Intervensi dilakukan selama 14 hari untuk setiap kelompok dosis, mulai hari kedua sampai hari kelima belas postpartum. Pengukuran berat badan dilakukan tiga kali sehari (M1: pengukuran awal, M2: 4 jam setelah M1, M3: satu jam setelah M2) pada hari ke 2, 4, 6, 8, 10, 12, 14, 16 postpartum. Konsumsi pakan diukur setiap hari. Produksi susu diukur berdasarkan perbedaan M1 dan M3 dalam pertambahan berat badan anakan. Sebelum menyusui, betina dipisahkan dengan anak-anaknya selama empat jam (Suprayogi et al., 2015).

\section{Analisis Data}

Data disajikan dalam mean \pm standar deviasi menggunakan Microsoft Excel 2013. Perbedaan antar perlakuan dianalisis menggunakan ANOVA. Perbedaan signifikan antara nilai rata-rata ditentukan menggunakan Uji Jarak Berganda Duncan $(\alpha=5 \%)$ menggunakan SPSS 16. Analisis korelasi dilakukan untuk mengetahui hubungan antara produksi susu, konsumsi pakan, pertumbuhan bobot badan tikus dan anakan.

\section{HASIL DAN PEMBAHASAN Produksi Susu dan Pertumbuhan Bobot Badan Anak Tikus}

Produksi susu 15 ekor tikus dihitung dari hari ke-2 sampai hari ke-16 laktasi dengan 8 kali pengamatan. Pengukuran produksi susu dihentikan pada hari ke-17, karena anak tikus telah memakan pelet yang dapat menyebabkan bias dalam mendapatkan data produksi susu (Mahmood et al., 2012). Tabel 1 menunjukkan rerata produksi susu tikus pada kelompok kontrol, dosis 1 dan dosis 2 (masing-masing 1,79 $\pm 0,89 ; 2,55 \pm 0,78$; $2,81 \pm 0,47 \mathrm{~g} /$ hari). Data menunjukkan bahwa produksi susu tikus tidak berbeda nyata antar kelompok perlakuan $(\mathrm{P}>0,05)$. Namun demikian terlihat bahwa pemberian ekstrak basah daun $P$. amboinicus baik dengan dosis 1 maupun dosis 2 memilki hasil produksi susu yang lebih tinggi dibandingkan dengan kontrol. Persentase kenaikan produksi susu pada dosis 1 mencapai $43 \%$ dan dosis 2 mencapai 57\% terhadap kontrol.

Total produksi susu tikus selama 8 hari pengamatan masa menyusui pada kelompok kontrol, dosis 1, dan dosis 2, masing-masing sebesar 16,09 g, 22,97 g, dan 25,25 g (Gambar 1). Produksi susu tertinggi pada kelompok kontrol didapatkan pada hari ke-8 sebesar 3,07, sedangkan dosis 1 didapatkan pada hari ke14 sebesar 5,24 g, dan pada dosis 2 didapatkan pada hari ke-8 sebesar 4,95 g (Gambar 1). Perlakuan ekstrak basah daun $P$. amboinicus menunjukkan hasil yang optimal untuk rata-rata peningkatan produksi susu pada hari ke 9-16 (Gambar 1), baik pada kontrol, dosis 1 , maupun dosis 2 (masing-masing $1,80 \pm 0,63 ; 3,10 \pm$ $0,89 ; 3,01 \pm 0,40)$.

Tabel 1 Rataan produksi susu, konsumsi pakan, pertumbuhan bobot badan tikus dan anakan hari ke 2-16 laktasi setelah tikus mengkonsumsi ekstrak basah daun P. amboinicus

\begin{tabular}{ccccc}
\hline Perlakuan & $\begin{array}{c}\text { Produksi } \\
\text { Susu }(\mathrm{g})\end{array}$ & $\begin{array}{c}\text { Pertumbuhan Bobot } \\
\text { Badan Tikus }(\mathrm{g})\end{array}$ & $\begin{array}{c}\text { Pertumbuhan Bobot } \\
\text { Badan Anak Tikus }(\mathrm{g})\end{array}$ & $\begin{array}{c}\text { Konsumsi } \\
\text { Pakan }(\mathrm{g})\end{array}$ \\
\hline Kontrol & $1,79 \pm 0,89^{\mathrm{a}}$ & $-0,43 \pm 0,49^{\mathrm{a}}$ & $13,39 \pm 0,29^{\mathrm{a}}$ & $13,14 \pm 0,33^{\mathrm{a}}$ \\
Dosis 1 & $2,55 \pm 0,78^{\mathrm{a}}$ & $-1,29 \pm 0,43^{\mathrm{a}}$ & $17,38 \pm 0,54^{\mathrm{a}}$ & $18,50 \pm 0,34^{\mathrm{a}}$ \\
Dosis 2 & $2,81 \pm 0,47^{\mathrm{a}}$ & $-1,79 \pm 0,94^{\mathrm{a}}$ & $18,43 \pm 0,21^{\mathrm{a}}$ & $18,86 \pm 0,18^{\mathrm{a}}$ \\
\hline
\end{tabular}

Huruf superscript (a) yang berbeda dalam satu kolom menunjukkan perbedaan nyata $(\mathrm{p}<0,05)$ 
Produksi susu tikus mengalami peningkatan selama menyusui kemungkinan terkait dengan peningkatan proliferasi sel kelenjar susu setelah diberi ekstrak basah daun P. amboinicus. Menurut Wall \& McFadden (2012), selama periode laktasi, sekresi susu tikus sangat dipengaruhi oleh banyaknya sel sekretori dan aktivitas sel. Sebaliknya, penurunan produksi ASI disebabkan oleh penurunan jumlah sel payudara atau pergantian sel selama menyusui. Berdasarkan pada Tabel 1, dapat dikatakan bahwa ekstrak basah daun $P$. amboinicus berpengaruh positif terhadap produksi susu tikus, sehingga dapat diduga bahwa ekstrak basah daun $P$. amboinicus mengandung senyawa aktif yang berfungsi untuk merangsang laktogenesis dan hormon laktasi.

Penelitian yang dilakukan ini sesuai dengan beberapa penelitian sebelumnya yang melaporkan bahwa pemberian soup dan ekstrak daun $P$. amboinicus dengan berbagai pelarut yang berbeda dapat memberikan respon positif untuk meningkatkan produksi susu pada tikus menyusui (Damanik et al., 2017; Damanik et al., 2006; Iwansyah et al., 2017). Daun $P$. amboinicus mengandung komponen fitokimia alkaloid, sterol, triterpenoid, tanin, dan flavonoid (Pillai et al., 2011; Elhawary et al., 2012). Menurut Mohanty et al., (2014), beberapa komponen seperti polifenol, tanin, dan alkaloid memiliki efek meningkatkan konsentrasi protein susu, produksi susu, sekresi susu, dan laju ovulasi. Pemberian ekstrak basah daun $P$. amboinicus kemungkinan memiliki kandungan fitoestrogenik dan beberapa molekul fitoestrogen memiliki efek yang mirip dengan 17 $\beta$-estradiol yang mendorong proliferasi sel epitel payudara (Foidart, 1998). Beberapa molekul fitoestrogen disebutkan, yaitu, diosgenin, estragole, silybin, shatavarine, kaempferol, dan quercetin, dapat menginduksi ekspresi reseptor prolaktin (PRLR), meningkatkan produksi kasein, dan aktivitas laktosa sintetase di sel epitel payudara (Tabares et al., 2014). Selain itu, senyawa flavonoid pada $P$. amboinicus (Wibisono et al., 2019) dapat merangsang pelepasan hormon prolaktin (PRL) dan hormon pertumbuhan $(\mathrm{GH})$, up-regulated prolactin hormone receptor (PRLR), dan ekspresi gen GHR, serta merangsang perkembangan payudara pada tikus (Guo et al., 2012).

Peningkatan produksi susu dengan pemberian ekstrak basah daun $P$. amboinicus mungkin juga dapat terjadi melalui mekanisme secara tidak langsung, yaitu ketika konsentrasi hormon steroid yang meningkat dalam aliran darah secara tidak langsung menstimulasi sel-sel kelenjar pituitary anterior dan posterior untuk melepaskan hormon prolaktin, growth hormone, dan oksitosin. Ketiga hormon ini secara langsung terlibat dalam sintesis air susu di kelenjar ambing (Suprayogi et al., 2001). Prajonggo et al., (1996) menduga bahwa kandungan sterol mempunyai peran dalam meningkatkan produksi susu secara hormonal.

Pengaruh senyawa aktif secara langsung maupun tidak langsung seiring lamanya pemberian perlakuan akan meningkatkan rataan produksi susu, hal ini terlihat bahwa pada hari ke-9 hingga hari ke-16 memberikan produksi susu yang lebih baik dibandingkan hari ke-1 hingga hari ke-8 (Tabel 2). Waktu optimal untuk melihat pengaruh pemberian ekstrak basah daun P. amboinicus terhadap produksi susu tikus diamati dari hari ke 2-16 laktasi dengan 8 pengamatan, yang disajikan pada Tabel 2. Data menunjukkan bahwa produksi susu tikus tidak berbeda nyata. Total produksi susu dari hari ke 1 sampai hari ke 8 terlihat adanya peningkatan produksi susu pada kelompok dosis 1 dan 2 dibandingkan dengan kelompok kontrol (masing-masing 2,00 $\pm 0,47,2,60 \pm 0,52$, $1,78 \pm 0,10)$. Demikian juga pada hari ke 9 sampai 16 terjadi peningkatan produksi susu pada kelompok dosis 1 dan 2 dibandingkan dengan kontrol (masing- 
masing 3,10 $\pm 0,89,3,01 \pm 0,40,1,80 \pm$ produksi susu yang lebih tinggi 0,63). Hari ke 9 sampai 16 menunjukkan dibandingkan hari ke 1 sampai ke 8 .
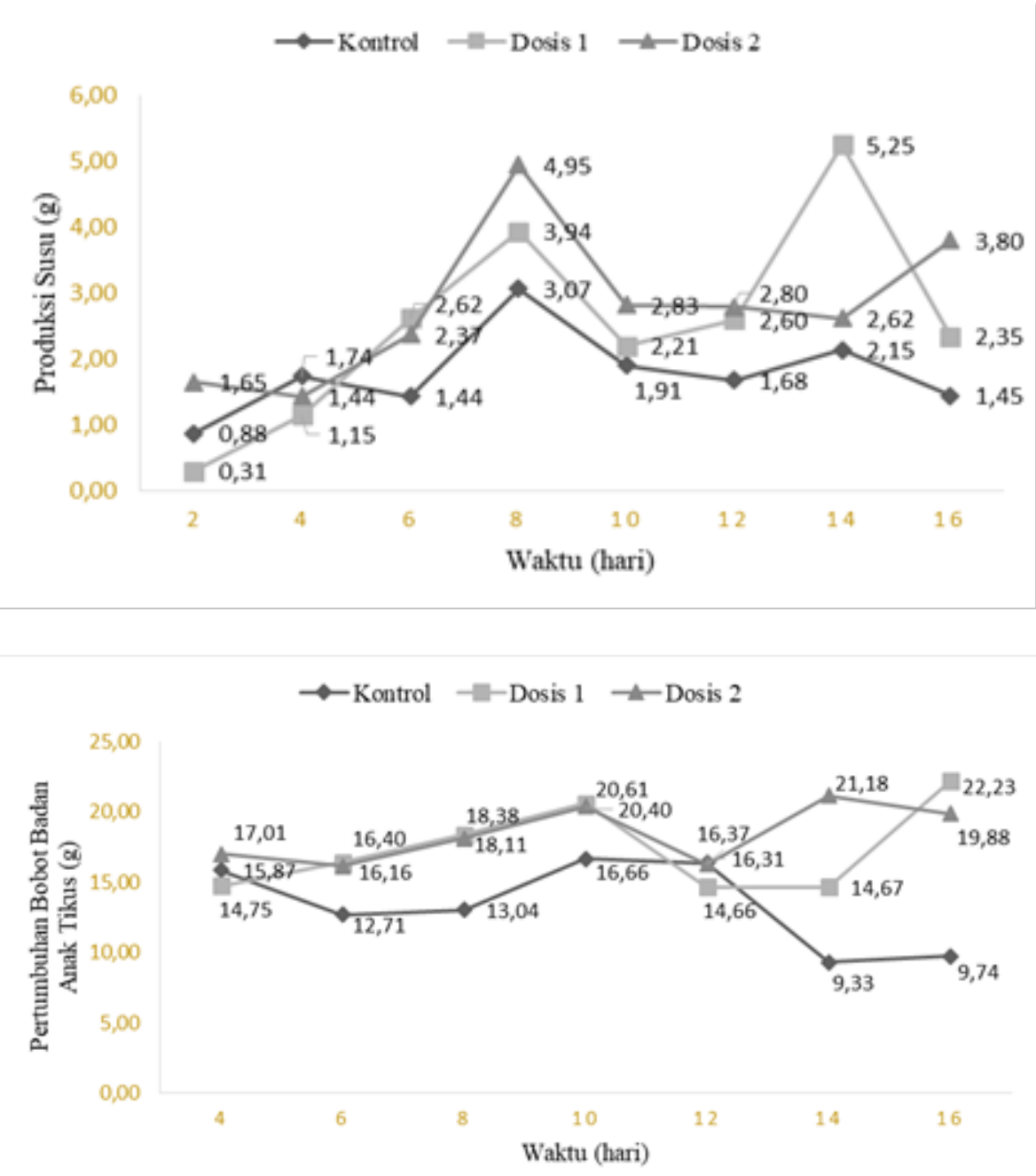

Gambar 1. Produksi susu dan pertumbuhan bobot badan anak tikus hari ke 2-16 laktasi setelah tikus mengkonsumsi ekstrak basah daun P. amboinicus

Peningkatan produksi susu ini sangat terkait dengan adanya peningkatan pertumbuhan bobot badan induk tikus. Gambaran respons positif produksi susu induk tikus dari ekstrak basah daun $P$. amboinicus tersebut memberikan gambaran yang serupa pada responsnya terhadap bobot badan anak tikus. Respons ekstrak basah daun $P$. amboinicus terhadap pertumbuhan bobot badan anak tikus disajikan pada Tabel 2. Respons pertumbuhan bobot badan anak tikus setelah induk mendapatkan ekstrak daun $P$. amboinicus pada hari ke-2 sampai hari ke-
8 maupun pada pemberian hari ke 9 sampai hari ke 16 tidak menunjukan adanya perbedaan nyata $(\mathrm{p}>0,05)$ antar kelompok. Namun demikian, pertumbuhan bobot anak tikus pada kelompok dosis 2 (Tabel 2) menunjukkan perbedaan yang signifikan $(\mathrm{p}<0,05)$ pada hari 1-8 dan 9-16 laktasi (masing-masing 17,09 $\pm 0,94 ; 19,44 \pm$ $0,49)$. Pertumbuhan bobot badan anak tikus pada kelompok dosis 1 dan 2 (Gambar 1) menunjukkan adanya peningkatan yang lebih tinggi dibandingkan dengan kelompok kontrol $(p>0.05)$. Persentase kenaikan pertumbuhan bobot badan anak tikus 
pada dosis 1 mencapai $30 \%$ dan dosis 2 mencapai $38 \%$ terhadap kontrol. Efek peningkatan bobot badan anak tikus mulai terlihat pada hari ke-6 sampai hari ke 16 (Gambar 1).

Tabel 2 Waktu optimal dari pengaruh pemberian ekstrak basah daun P. amboinicus terhadap produksi susu dan petumbuhan bobot badan anak tikus hari ke 1-16 laktasi

\begin{tabular}{|c|c|c|c|c|c|c|}
\hline \multirow{2}{*}{$\begin{array}{c}\text { Hari } \\
\text { ke- }\end{array}$} & \multicolumn{3}{|c|}{ Produksi Susu (g) } & \multicolumn{3}{|c|}{ Pertumbuhan Bobot Badan Anak Tikus (g) } \\
\hline & Kontrol & Dosis 1 & Dosis 2 & Kontrol & Dosis 1 & Dosis 2 \\
\hline $1-8$ & $1,78 \pm 0,10^{\mathrm{aA}}$ & $2,00 \pm 0,47^{\mathrm{aA}}$ & $2,60 \pm 0,52^{\mathrm{aA}}$ & $13,87 \pm 0,45^{\mathrm{aA}}$ & $16,51 \pm 0,59^{\mathrm{aA}}$ & $17,09 \pm 0,94^{\mathrm{aA}}$ \\
\hline $9-16$ & $1,80 \pm 0,63^{\mathrm{aA}}$ & $3,10 \pm 0,89^{\mathrm{aA}}$ & $3,01 \pm 0,40^{\mathrm{aA}}$ & $13,02 \pm 0,36^{\mathrm{aA}}$ & $18,04 \pm 0,76^{\mathrm{aA}}$ & $19,44 \pm 0,49^{\mathrm{aB}}$ \\
\hline
\end{tabular}

Penelitian ini juga melihat jumlah susu yang dikonsumsi anak tikus. Susu yang dikonsumsi anak tikus umumnya digunakan untuk pertumbuhan dan pemeliharaan tubuh anak tikus. Maka pembatasan jumlah dan keseragaman ukuran anak tikus dalam setiap kelompok menjadi penting untuk dilakukan agar kebutuhan susu untuk anak tikus tercukupi untuk pertumbuhan yang maksimal. Menurut Mahmood et al., (2012), pertumbuhan tikus sangat dipengaruhi oleh kuantitas susu yang tersedia selama masa menyusui.

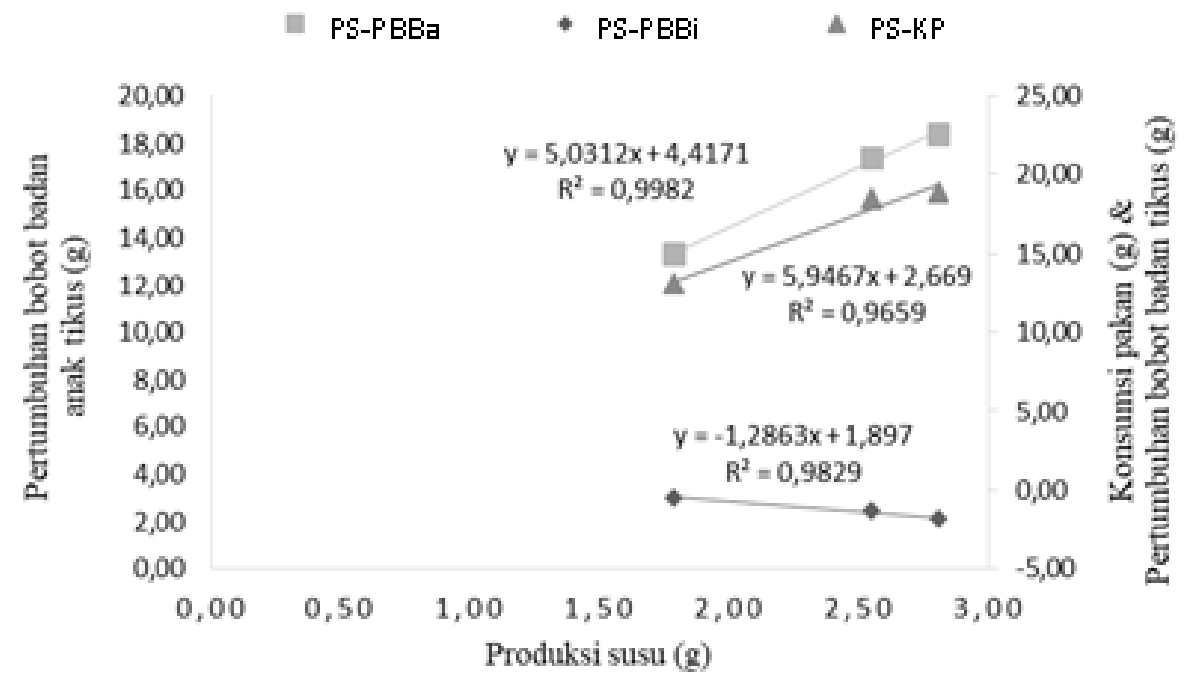

Gambar 2. Korelasi antara produksi susu dengan pertumbuhan bobot badan anak tikus (PS$\mathrm{PBBa}$ ), produksi susu dengan pertumbuhan bobot badan tikus (PS-PBBi), dan produksi susu dengan konsumsi pakan (PS- KP) hari ke 2-16 laktasi setelah tikus mengkonsumsi ekstrak basah daun $P$. amboinicus

Pengaruh pemberian ekstrak basah daun $P$. amboinicus terhadap pertumbuhan bobot badan anak tikus, berkorelasi positif terhadap produksi susu induk (Gambar 2). Pengamatan pertumbuhan bobot badan anak tikus pada semua kelompok perlakuan selama 8 hari pengamatan berkorelasi positif dengan meningkatnya produksi susu tikus dengan nilai $\mathrm{R}^{2} 0,9882$. Pertambahan bobot badan anak tikus ini kemungkinan juga disebabkan karena adanya senyawa aktif daun $P$. amboinicus yang dikonsumsi anak tikus melalui susu induk. Di dalam ekstrak daun $P$. 
amboinicus mengandung senyawa sterol (Pillai et al., 2011; El-hawary et al., 2012) yang mempunyai peranan dalam meningkatkan produksi susu secara hormonal dengan merangsang hormon estrogen yang merupakan hormon pertumbuhan (Prajonggo et al., 1996). Keberadaan hormon pertumbuhan ini diperkirakan mampu memacu pertumbuhan sel dan dapat menambah bobot badan anak tikus.

Respons pertumbuhan bobot badan anak tikus setelah induk mendapatkan perlakuan ekstrak basah daun $P$. amboinicus dari hari ke-2 sampai hari ke16 menunjukkan peningkatan (Tabel 1) dibandingkan dengan kelompok kontol $(\mathrm{P}>0,05)$. Rataan penambahan bobot badan anak tikus (Tabel 1) dengan perlakukan dosis 2 menunjukkan hasil tertinggi dibandingkan kelompok dosis 1 dan kontrol (masing-masing 18,43 $\pm 0,21$; $17,38 \pm 0,54 ; 13,39 \pm 0,29)$. Pengaruh pemberian ekstrak basah daun $P$. amboinicus terhadap pertambahan bobot badan anak tikus sesuai dengan produksi susu induk. Hal ini sejalan dengan penelitian sebelumnya yang menyatakan peningkatan rataan pertumbuhan bobot badan anak tikus berkorelasi positif dengan peningkatan produksi susu ketika diberi ekstrak daun katuk (Suprayogi et al., 2015) dan pada kambing etawa yang diberi simplisia daun $P$. amboinicus (Rumetor, 2008).

\section{Pertumbuhan Bobot Badan Tikus dan Konsumsi Pakan}

Secara umum asupan pakan bagi tikus menyusui pada setiap kelompok perlakuan mendapatkan asupan zat gizi atau energi yang sama. Tabel 1 menunjukkan bahwa pemberian ekstrak basah daun $P$. amboinicus pada dosis 1 dan 2 memiliki kecenderungan untuk menurunan rataan bobot badan induk ( $p>0.05)$ dibandingkan kelompok kontrol (masing-masing $-1,29 \pm 0,43 ;-1,79 \pm 0,94$;
$-0,43 \pm 0,49)$. Persentase penurunan pertumbuhan berat badan tikus dosis 1 mencapai $-200 \%$ dan dosis 2 mencapai $316 \%$ terhadap kontrol. Dan menariknya, meski jumlah bobot badan tikus mengalami penurunan, namun rataan konsumsi pakan (Tabel 1) mengalami peningkatan $(\mathrm{p}>0.05)$ setelah diberikan perlakuan ekstrak basah daun $P$. amboinicus pada dosis 1 dan 2 dibandingkan dengan kontrol (masingmasing $18,50 \pm 0,34 ; 18,86 \pm 0,18 ; 13,14 \pm$ 0,33). Persentase kenaikan konsumsi pakan pada dosis 1 mencapai $41 \%$ dan dosis 2 mencapai 44\% terhadap kontrol.

Gambar 3 menyajikan nilai konsumsi pakan per hari dan pertumbuhan bobot badan tikus selama 16 hari laktasi. Asupan gizi sangat mempengaruhi fisiologi, kesehatan, bahkan hingga kecerdasan (Horta et al., 2018). Asupan gizi tersebut perlu diperhatikan sejak mulai masa kebuntingan dan laktasi (Sultana et al., 2013). Konsumsi pakan menunjukkan adanya perbedaan antara kelompok perlakuan dosis 1, dosis 2 dan kontrol ( $>0,05)$. Konsumsi pakan pada kelompok perlakuan dosis 1 dan 2 mendapatkan asupan nutrisi atau energi yang lebih besar dibandingkan kontrol. Hal tersebut menunjukkan bahwa pemberian perlakuan ekstrak basah daun $P$. amboinicus mempengaruhi palatabilitas pakan bagi tikus.

Gambaran nilai asupan pakan pada setiap kelompok perlakuan ini, ternyata tidak diikuti dengan gambaran yang sama pada pertumbuhan bobot badan tikus pada setiap kelompok perlakuan dan memiliki korelasi negatif dengan produksi susu (Gambar 2). Hal ini mengindikasikan bahwa pemberian ekstrak basah daun $P$. amboinicus menunjukkan adanya penurunan atau penghambatan pertumbuhan. Penghambatan pertumbuhan ini kemungkinan diakibatkan oleh senyawa aktif yang berada di ekstrak tersebut, mengingat rataan jumlah asupan pakan 
menunjukkan adanya peningkatan untuk kelompok perlakuan ekstrak basah daun $P$. amboinicus dibandingkan kontrol. Sedangkan penambahan konsumsi pakan sesuai dengan penelitian sebelumnya yang menyebutkan bahwa mencit fase laktasi akan makan lebih banyak untuk memenuhi kebutuhan asupan bagi anak dan dirinya sendiri (Malole \& Pramono, 1989)
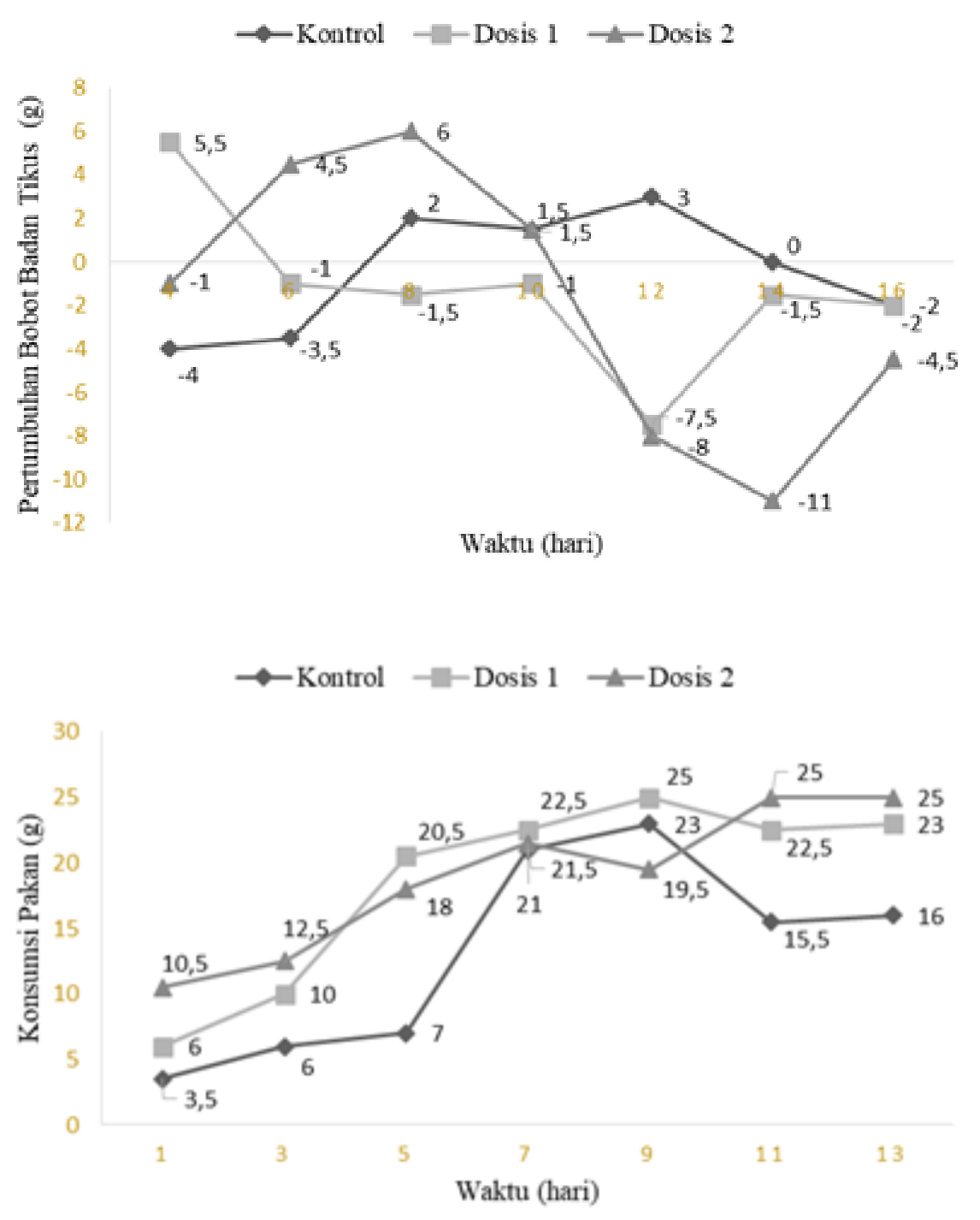

Gambar 3 Pertumbuhan bobot badan tikus dan konsumsi pakan hari ke 2-16 laktasi setelah tikus mengkonsumsi ekstrak basah daun P. amboinicus

Sampai saat ini belum diketahui secara pasti senyawa apa yang menjadi penyebab penghambatan ini. Namun kemungkinan senyawa alkaloid seperti yang dilaporkan oleh Bender \& Ismail (1974) dapat menimbulkan efek pada penghambatan pertumbuhan bobot badan tikus. Senyawa ini telah dilaporkan memiliki efek toksisitas pada gadis-gadis di Taiwan sebagai pelangsing tubuh atau kontrol bobot badan (Chang et al., 1998). (Yu et al., 2007) melaporkan bahwa efek toksisitas dapat terjadi karena adanya penghambatan pertumbuhan sel fibroblast melalui proses apoptosis maupun nekrosis. Gambaran penurunan bobot badan pada 
tikus sebagai akibat mengkonsumsi ekstrak daun $P$. amboinicus dalam pakan selama 14 hari juga telah dilaporkan (Iwansyah et al., 2017). Kecenderungan penurunan bobot badan tikus berhubungan dengan pertambahan bobot badan anak, hal ini karena bobot air dalam tubuh dan hormon yang dilepaskan oleh tubuh ketika menyusui mengakibatkan kontraksi otot di rahim, kemudian rahim akan berkontraksi dan menyusut. Selain itu, menyusui membutuhkan banyak kalori untuk memproduksi susu pada manusia dan berhubungan dengan tingginya kalori pada susu yang dihasilakan (Powe et al., 2010).

Tabel 3 Waktu optimal dari pengaruh pemberian ekstrak basah daun P. amboinicus terhadap pertumbuhan bobot badan tikus dan konsumsi pakan hari ke 1-16 laktasi

\begin{tabular}{|c|c|c|c|c|c|c|}
\hline \multirow{2}{*}{$\begin{array}{c}\text { Hari } \\
\text { ke- }\end{array}$} & \multicolumn{3}{|c|}{ Pertumbuhan Bobot Badan Tikus (g) } & \multicolumn{3}{|c|}{ Konsumsi Pakan (g) } \\
\hline & Kontrol & Dosis 1 & Dosis 2 & Kontrol & Dosis 1 & Dosis 2 \\
\hline $1-8$ & $-1,83 \pm 0,93^{\mathrm{aA}}$ & $1,00 \pm 0,76^{\mathrm{aA}}$ & $3,17 \pm 0,45^{\mathrm{aA}}$ & $9,38 \pm 0,12^{\mathrm{aA}}$ & $14,75 \pm 0,61^{\mathrm{aA}}$ & $15,63 \pm 0,70^{\mathrm{aA}}$ \\
\hline $9-16$ & $0,63 \pm 0,71^{\mathrm{aA}}$ & $-3,00 \pm 0,24^{\mathrm{aA}}$ & $-5,50 \pm 0,40^{\mathrm{aB}}$ & $18,17 \pm 0,18^{\mathrm{aA}}$ & $23,50 \pm 0,14^{\mathrm{aB}}$ & $23,17 \pm 0,67^{\mathrm{aB}}$ \\
\hline
\end{tabular}

Huruf superscript (a) yang berbeda dalam satu baris menunjukkan perbedaan nyata $(\mathrm{p}<0.05)$

Huruf superscript (A-B) yang berbeda dalam satu satu kolom menunjukkan perbedaan nyata $(\mathrm{p}<0.05)$

Senyawa aktif yang terkandung dalam ekstrak basah daun $P$. amboinicus secara langsung maupun tidak langsung berpengaruh terhadap rataan pertumbuhan bobot badan tikus dan konsumsi pakan, hal ini terlihat bahwa pada hari ke-9 hingga hari ke-16 memberikan kenaikan jumlah konsumsi pakan pada semua perlakuan dibandingkan dengan kontrol pada hari ke1 hingga hari ke-8. Namun demikian, kenaikan konsumsi pakan tidak berkorelasi positif pada kenaikan bobot badan tikus. Tabel 3 memperlihatkan bahwa terjadi penurunan pertumbuhan bobot badan tikus disemua perlakuan pada hari ke-9 hingga hari ke-16 dibandingkan kelompok kontrol hari ke-1 hingga hari ke-8 (Tabel 3). Waktu optimal untuk melihat pengaruh pemberian ekstrak basah daun $P$. amboinicus terhadap penurunan pertumbuhan bobot badan tikus (Tabel 3) ialah dari hari ke-9 hingga hari ke-16 baik pada dosis 1 dan dosis 2 dibandingkan kelompok kontrol (masingmasing $-3,00 \pm 0,24 ;-5,50 \pm 0,40 ; 0,63 \pm$ 0,71). Pada dosis 2 juga didapatkan perbedaan hasil yang signifikan $(p<0,05)$ dalam penurunan pertumbuhan bobot badan tikus di hari ke-9 hingga hari ke-16 dibandingkan dengan hari ke-1 hingga hari ke-8 (Tabel 2). Konsumsi pakan tikus yang diberikan perlakuan ekstrak basah daun $P$. amboinicus pada dosis 1 dan 2 memperlihatkan hasil kenaikan jumlah konsumsi pakan yang signifikan $(\mathrm{p}<0,05)$ pada hari ke-9 hingga hari ke-16 dibandingkan dengan hari ke-1 hingga hari ke-8 (Tabel 3). Dan pada Tabel 3 juga memperlihatkan bahwa pemberian perlakuan ekstrak basah daun $P$. amboinicus pada dosis 1 dan dosis 2 terhadap konsumsi pakan tikus menunjukkan peningkatan jumlah konsumsi pakan $(\mathrm{p}>0,05)$.

\section{KESIMPULAN}

Pada penelitian ini dapat disimpulkan bahwa pemberian ekstrak basah daun Plectranthus amboinicus (L.) pada tikus dengan dosis $324 \mathrm{mg} / \mathrm{kgBB}$ dapat meningkatkan produksi susu tikus, pertumbuhan bobot badan anak tikus, dan konsumsi pakan. Namun demikian, pemberian perlakuan ekstrak basah daun $P$. amboinicus dapat memberikan penurunan pertumbuhan bobot badan tikus. Waktu optimal untuk melihat efektivitas pemberian ekstrak basah daun $P$. amboinicus terdapat pada hari ke-9 hingga hari ke-16 terhadap produksi susu, pertumbuhan bobot badan anak tikus, serta 
konsumsi pakan. Peningkatan produksi susu berkorelasi positif dengan pertumbuhan bobot badan anak tikus dan konsumsi pakan tikus. Di sisi lain, produksi susu berkorelasi negatif dengan pertumbuhan berat badan tikus.

\section{SUMBER DANA PENELITIAN}

Penelitian ini didukung oleh hibah untuk penelitian ilmiah dari Kementerian Riset dan Teknologi Republik Indonesia dalam program Calon Perusahaan Pemula Berbasis Teknologi Tahun 2019.

\section{DAFTAR PUSTAKA}

Aguiar, J. J. S., Sousa, C. P. B., Araruna, M. K. A., Silva, M. K. N., Portelo, A. C., Lopes, J. C., Carvalho, V. R. A., Figueredo, F. G., Bitu, V. C. N., Coutinho, H. D. M., Miranda, T. A. S., \& Matias, E. F. F. (2015). Antibacterial and modifyingantibiotic activities of the essential oils of Ocimum gratissimum L. and Plectranthus amboinicus L. European Journal of Integrative Medicine, $\quad 7(2), \quad$ 151-156. https://doi.org/10.1016/j.eujim.2014. 10.005

Akagawa, S., Tsuji, S., Onuma, C., Akagawa, Y., Yamaguchi, T., Yamagishi, M., Yamanouchi, S., Kimata, T., Sekiya, S., Ohashi, A., Hashiyada, M., Akane, A., \& Kaneko, K. (2019). Effect of Delivery Mode and Nutrition on Gut Microbiota in Neonates. Annals of Nutrition and Metabolism, 74(2), 132-139. https://doi.org/10.1159/000496427

Belfort, M. B., Anderson, P. J., Nowak, V. A., Lee, K. J., Molesworth, C., Thompson, D. K., Doyle, L. W., \& Inder, T. E. (2016). Breast Milk Feeding, Brain Development, and Neurocognitive Outcomes: A 7-Year Longitudinal Study in Infants Born at Less Than 30 Weeks' Gestation. The
Journal of Pediatrics, 177, 133139.e1.

https://doi.org/10.1016/j.jpeds.2016. 06.045

Belfort, M. B., Rifas-Shiman, S. L., Kleinman, K. P., Guthrie, L. B., Bellinger, D. C., Taveras, E. M., Gillman, M. W., \& Oken, E. (2013). Infant Feeding and Childhood Cognition at Ages 3 and 7 Years: Effects of Breastfeeding Duration and Exclusivity. JAMA Pediatrics, 167(9), 836. https://doi.org/10.1001/jamapediatri cs. 2013.455

Bhatt, P., Joseph, G. S., Negi, P. S., \& Varadaraj, M. C. (2013). Chemical Composition and Nutraceutical Potential of Indian Borage ( Plectranthus amboinicus ) Stem Extract. Journal of Chemistry, 2013, $1-7$.

https://doi.org/10.1155/2013/320329

Bhattacharya, R., Dev, K., \& Sourirajan, A. (2021). Antiviral activity of bioactive phytocompounds against coronavirus: An update. Journal of Virological Methods, 290, 114070. https://doi.org/10.1016/j.jviromet.20 21.114070

Brandao, E. M., Brandão, P. H. D. M., Souza, I. A., Paiva, G. S., de C. Carvalho, M., \& Lacerda, C. M. (2013). Antineoplasic Effect of Aqueous Extract of Plectranthus Amboinicus in Ehrlich Ascites Carcinoma. Journal of Cancer, 4(7), 573-576. https://doi.org/10.7150/jca.6730

Chang, Y.-L., Yao, Y.-T., Wang, N.-S., \& Lee, Y.-C. (1998). Segmental Necrosis of Small Bronchi after Prolonged Intakes of Sauropus androgynus in Taiwan. American Journal of Respiratory and Critical Care Medicine, 157(2), 594-598. https://doi.org/10.1164/ajrccm.157.2 .9704040 
Chen, Y.-S., Yu, H.-M., Shie, J.-J., Cheng, T.-J. R., Wu, C.-Y., Fang, J.-M., \& Wong, C.-H. (2014). Chemical constituents of Plectranthus amboinicus and the synthetic analogs possessing anti-inflammatory activity. Bioorganic \& Medicinal Chemistry, 22(5), 1766-1772. https://doi.org/10.1016/j.bmc.2014.0 1.009

Damanik, R., Ao, M. L. W., \& Wattanapenpaiboon, N. (2006). Lactagogue effects of Torbangun, a Bataknese traditional cuisine. Asia Pac J Clin Nutr, 15(2), 267-274.

Damanik, R. M., Kustiyah, L., Hanafi, M., \& Iwansyah, A. C. (2017). Evaluation Lactogenic Activity of Ethyl Acetate Fraction of Torbangun ( Coleus amboinicus L.) Leaves. IOP Conference Series: Earth and Environmental Science, 101, 012007.

https://doi.org/10.1088/17551315/101/1/012007

Desai, G., Sunil Kumar, G., Manoj, L., Gokul, G. R., Beena, K. V., Thennarasu, K., \& Jaisoorya, T. S. (2019). Prevalence \& correlates of chronic perinatal pain - a study from India. Journal of Psychosomatic Obstetrics \& Gynecology, 40(2), 9196.

https://doi.org/10.1080/0167482X.2 017.1405258

El-hawary, S. S., El-sofany, R. H., AbdelMonem, A. R., Ashour, R. S., \& Sleem, A. A. (2012). Polyphenolics content and biological activity of Plectranthus amboinicus (Lour.) spreng growing in Egypt (Lamiaceae). Pharmacognosy Journal, 4(32), 45-54. https://doi.org/10.5530/pj.2012.32.9

Fati, N., Irda, I., \& Syukriani, D. (2014). Using of Bangun-Bangun Leafs (Coleus Amboinicus, L) on Red Sugar Block to Upgrading Milk
Production of Frisian Holstein. International Journal on Advanced Science, Engineering and Information Technology, 4(2), 84. https://doi.org/10.18517/ijaseit.4.2.3 74

Foidart, J. (1998). Estradiol and Progesterone Regulate the Proliferation of Human Breast Epithelial Cells. Fertility and Sterility, 69(5), 963-969. https://doi.org/10.1016/S00150282(98)00042-9

Govindaraju, S., \& Arulselvi, P. I. (2018). Characterization of Coleus aromaticus essential oil and its major constituent carvacrol for in vitro antidiabetic and antiproliferative activities. Journal of Herbs, Spices \& Medicinal Plants, 24(1), 37-51. https://doi.org/10.1080/10496475.20 17.1369483

Grzeskowiak, L. E., Wlodek, M. E., \& Geddes, D. T. (2019). What Evidence Do We Have for Pharmaceutical Galactagogues in the Treatment of Lactation Insufficiency?-A Narrative Review. Nutrients, 11(5), 974.

https://doi.org/10.3390/nu11050974

Guo, X., Diao, Q., Wang, Y., Tu, Y., Deng, K., Wang, X., Fu, T., \& Yan, G. (2012). The Effect of Administration of Rutin on Plasma Levels of Estrogen, Prolactin, Growth Hormone and Gene Expression of Their Receptors in Mammary Glands in Ovariectomized Rats. Journal of Integrative Agriculture, 11(10), 1700-1706. https://doi.org/10.1016/S20953119(12)60173-7

He, S., \& Xia, H. (2019). The relationship between neutrophil-lymphocyte ratio and onset of lactation among postpartum women: A prospective observational cohort study. International Journal of Nursing 
Studies, 97, 55-62. https://doi.org/10.1016/j.ijnurstu.201 9.05.005

Horta, B. L., Hartwig, F. P., \& Victora, C. G. (2018). Breastfeeding and intelligence in adulthood: Due to genetic confounding? The Lancet Global Health, 6(12), e1276-e1277. https://doi.org/10.1016/S2214109X(18)30371-1

Iwansyah, A. C., Damanik, M. R. M., Kustiyah, L., \& Hanafi, M. (2017). Potensi Fraksi Etil Asetat Daun Torbangun (Coleus amboinicus L.) dalam Meningkatkan Produksi Susu, Bobot Badan Tikus, dan Anak Tikus. Jurnal Gizi dan Pangan, 12(1), 6168.

https://doi.org/10.25182/jgp.2017.12 .1.61-68

Kociszewska-Najman, B., Sibanda, E., Radomska-Leśniewska, D. M., Taradaj, K., Kociołek, P., Ginda, T., Gruszfeld, M., Jankowska-Steifer, E., Pietrzak, B., Wielgoś, M., \& Malejczyk, J. (2020). Does Caesarean Section or Preterm Delivery Influence TGF- $\beta 2$ Concentrations in Human Colostrum? Nutrients, 12(4), 1095. https://doi.org/10.3390/nu12041095

Kumari, B. P., Sujatha, D., Chand, C. G., Divya, K., Malleswari, I., \& Ranganayakulu, D. (2012). Evaluation of antiepileptic activity and probable mechanism of action of Coleus amboinicus in MES and PTZ models. Journal of Pharmacy Research, 3, 6.

Li, D., Jiang, Y., Ma, X., Li, Q., Chu, X., Zhong, W., Deng, X., \& Yang, X. (2021). The effect of pestle acupuncture for patients with lactation insufficiency after cesarean section: Study protocol for a randomized controlled trial. Medicine, 100(3), e23808. https://doi.org/10.1097/MD.000000

\section{8}

Mahmood, A., Omar, M. N., \& Ngah, N. (2012). Galactagogue effects of Musa x paradisiaca flower extract on lactating rats. Asian Pacific Journal of Tropical Medicine, 5(11), 882886. https://doi.org/10.1016/S19957645(12)60164-3

Mohanty, I., Senapati, M. R., Jena, D., \& Behera, P. C. (2014). Ethnoveterinary importance of herbal galactogogues-A review. Veterinary World, 7(5), 325-330. https://doi.org/10.14202/vetworld.20 14.325-330

Nengsih, R. F., Mustika, A. A., \& Andriyanto. (2020). Evaluasi Gambaran Darah dan Marker Stres (Rasio H/L) Ayam Pedaging yang Diberi Daun Bangun-Bangun selama 28 Hari. Acta Veterinaria Indonesiana, 8(2), 9-15.

Pillai, P. G., Suresh, P., Aggarwal, G., Doshi, G., \& Bhatia, V. (2011). Plectranthus amboinicus (Lour) Spreng. Journal of Applied Pharmaceutical Science, 1(2), 7581.

Purwantari, N. D., \& Sutedi, E. (2011). Pengaruh Interval Potong terhadap Produktivitas dan Kualitas Tanaman Bangun-Bangun (Coleus amboinicus L.) sebagai Komoditas Harapan Pakan Ternak. JITV, 16(4), 288-293. Rumetor, S. D. (2008). Suplementasi Daun Bangun-Bangun (Coleus amboinicus Lour) dan Zinc-Vitamin E dalam Ransum untuk Memperbaiki Metabolisme dan Produksi Susu Kambing Peranakan Etawah. 188.

Selvakumar, P., naveena, B. E., \& prakash, S. D. (2012). Studies on the antidandruff activity of the essential oil of coleus amboinicus and eucalyptus globulus. Asian Pacific Journal of Tropical Disease, 2, S715-S719.

https://doi.org/10.1016/S2222- 
1808(12)60250-3

Shubha, J. R., \& Bhatt, P. (2015). Plectranthus amboinicus leaves stimulate growth of probiotic L. plantarum: Evidence for ethnobotanical use in diarrhea. Journal of Ethnopharmacology, 166, 220-227.

https://doi.org/10.1016/j.jep.2015.02 .055

Silva, O. L. de O., Rea, M. F., Sarti, F. M., \& Buccini, G. (2020). Costeffectiveness analysis of BabyFriendly Hospital Initiative in promotion of breast-feeding and reduction of late neonatal infant mortality in Brazil. Public Health Nutrition, 1-11. https://doi.org/10.1017/S136898002 0001871

Sultana, A., Rahman, K. U. R., \& Manjula, S. (2013). Clinical Update and Treatment of Lactation Insufficiency. Medical Journal of Islamic World Academy of Sciences, 21(1), 19-28. https://doi.org/10.12816/0000207

Suprayogi, A., ter Meulen, U., Ungerer, T., Manalu, W. (2001). Population of secretory cells and synthetic activities in mammary gland of lactating sheep after consuming Sauropus androgynus (L.) Merr. leaves. Indones J Trop Agric, 10(1), 1-3.

Suprayogi, A., Kusumorini, N., \& Arita, S. E. D. (2015). Fraksi Heksan Daun Katuk Sebagai Obat Untuk Memperbaiki Produksi Susu, Penampilan Induk, dan Anak Tikus. Jurnal Veteriner, 16(1), 88-95.

Suresh, S., Muthukrishnan, L., Vennila, S., K., G., J., A. L., Paiman, S., Faruq, M., Al-Lohedan, H. A., Akbarzadeh, O., \& Oh, W. C. (2020). Mechanistic anticarcinogenic efficacy of phytofabricated gold nanoparticles on human lung adenocarcinoma cells. Journal of Experimental Nanoscience, $\quad$ 15(1), 160-173. https://doi.org/10.1080/17458080.20 20.1761014

Tabares, F., Bedoya Jaramillo, J. V., \& Ruiz-Cortés, Z. T. (2014). Pharmacological Overview of Galactogogues. Veterinary Medicine International, 2014, 1-20. https://doi.org/10.1155/2014/602894

Takahashi, T. (2021). Sensory Stimulation of Oxytocin Release Is Associated With Stress Management and Maternal Care. Frontiers in Psychology, 11, 588068. https://doi.org/10.3389/fpsyg.2020.5 88068

Wall, E. H., \& McFadden, T. B. (2012). Triennial Lactation Symposium: A local affair: How the mammary gland adapts to changes in milking frequency1,2. Journal of Animal Science, 90(5), 1695-1707. https://doi.org/10.2527/jas.20114790

Wibisono, K., Aisyah, S. I., Suhesti, S., \& Nurcholis, W. (2019). Optimization of Total Flavonoids Extraction and A-Glucosidase Inhibitory Activity from Plectranthus amboinicus (Lour.) Spreng. Leaves using the Simplex-Centroid Design. Molekul, 14(2), 84. https://doi.org/10.20884/1.jm.2019.1 4.2.497

Yanza, Y. R., Szumacher-Strabel, M., Bryszak, M., Gao, M., Kolodziejski, P., Stochmal, A., Slusarczyk, S., Patra, A. K., \& Cieslak, A. (2018). Coleus amboinicus (Lour.) leaves as a modulator of ruminal methanogenesis and biohydrogenation in vitro. Journal of Animal Science. https://doi.org/10.1093/jas/sky321

Yu, S.-F., Chen, T.-M., \& Chen, Y.-H. (2007). Apoptosis and Necrosis are Involved in the Toxicity of Sauropus androgynus in an In Vitro Study. Journal of the Formosan Medical 
Association, 106(7), 537-547. https://doi.org/10.1016/S09296646(07)60004-7

Zhang, B., Wijesundara, N. M., Abbey, Lord, \& Rupasinghe, H. P. V. (2017). Growing medium amendments effect on growth, secondary metabolites and anti-streptococcal activity of two species of Plectranthus. Journal of Applied Research on Medicinal and Aromatic Plants, 5, 53-59. https://doi.org/10.1016/j.jarmap.201 6.11 .001 